2. Centers for Disease Control. Protection against viral hepatitis. Recommendations of the Immunization Practices Advisory Committee (ACIP). MMWR 1990;39(No.RR 2):5-22.

3. Centers for Disease Control. Recommendations for preventing transmission of human immunodeficiency virus and hepatitis B virus to patients during exposure-prone procedures. M M WR 1991;40:1-9.

4. Cardo D, Srivastava P Ciesielski D, et al. Case-control study of HIV-seroconversion in health care workers after percutaneous exposure to HIV-infected blood. Abstracts of the 34th Annual ICAAC Meeting; October, 1994; Orlando, FL. Abstract \#I236, p 237.

5. Henderson DK. Human immunodeficiency virus infection in patients and providers. In: Wenzel RP: ed. Prevention and Control of N osocomial Infections. 2nd ed. Baltimore, MD: Williams and Wilkins; 1993:42-57.

6. Sherertz RJ, Marosok RD. Streed SA. Infection control aspects of hospital employee health. In: Wenzel RP: ed. Prevention and Control of N osocomial Infections. 2nd ed. Baltimore, MD: Williams and Wilkins; 1993:295-332.

7. Polder JA, Tablan OC, Williams WW Personnel health services. In: Bennett JV, Brachman PS, eds. Hospital Infections. 3rd ed. Boston, MA: Little, Brown and Co; 1992:31-61.

8. Patterson WB, Craven DE, Schwartz DA, et al. Occupational hazards to hospital personnel. A nn Intern M ed 1985;102:658-680.

9. Centers for Disease Control. Update: universal precautions for prevention of transmission of human immunodeficiency virus, hepatitis B virus, and other bloodborne pathogens in health-care settings. M M WR 1988;37:377-382, 387-388.

10. Doebbeling BN, Wenzel RP Nosocomial viral hepatitis and infections transmitted by blood and blood products. In: Mandell GL, Bennett JE, Dolin R, eds. Principles and Practice of Infectious Diseases. 4th ed. New York, NY: Churchill Livingstone; 1995:26162632.

11. Gerberding JL, Henderson DK. Management of occupational exposures to bloodborne pathogens: hepatitis B virus, hepatitis $\mathrm{C}$ virus, and human immunodeficiency virus. Clin Infect $\mathrm{D}$ is 1992;14:1179-1185.

12. Benenson AS, ed. Control of Communicable Diseases in $M$ an. 15th ed. Washington, DC: American Public Health Association; 1990.

13. Lewy R. Organization and conduct of a hospital occupational health service. State of the art reviews. Occup M ed 1987;2:617638.

14. Hoffman KK, Weber DJ. Rutala WA Infection control strategies relevant to employee health. AORNJ 1991;39:167-181.

\title{
UCSF Distributes HIV Prevention Fact Sheets to Answer Common Questions
}

\section{by Gina Pugliese, RN, MS Medical News Editor}

Researchers at the University of California at San Francisco (UCSF) have created fact sheets to answer common questions about HIV preven- tion. In an effort to make HIV prevention behavioral research findings more widely available, the fact sheets are being distributed to policy makers, legislators, research funding agencies, and community-based HIV prevention programs. The fact sheets are part of
"Looking Back-Looking Ahead," a 2-year project devoted to studying and disseminating information on HIV behavioral research. The project is cosponsored by the UCSF Center for AIDS Prevention Studies and the Harvard AIDS Institute. 